\title{
Heat Waves in the City of Gaziantep in Turkey
}

\author{
Gülşen Kum \\ Department of Geography, Gaziantep University, Gaziantep /Turkey
}

\begin{abstract}
In this study, the duration, frequency and the impact of heat waves on comfort conditions, experienced particularly in the summers, have been examined with the purpose of revealing how the annual and monthly temperatures in Gaziantep, a city located in the South Eastern district of Turkey, are affected by the global climate change. Initially, the data on minimum, maximum and average heat in the period from 1940 to 2015, retrieved from the Meteorological Station in the city center, were analyzed using the Mann-Kendall trend analysis, which is a non-parametric test, and the increase/decrease trends in temperature parameters were determined. Afterwards, the impact of heat waves on the comfort levels was demonstrated using the "Heat Index (apparent temperature)" method by Steadman (1979), analyzing the heat waves that are predicted to increase in rate and frequency with the climate change, even though the statistical distributions remain the same. According to the results produced by the Heat Index method, it is estimated that the temperatures in the region will shift towards a warmer climate in terms of thermal conditions. It is believed that this study will be highly instrumental in prompting necessary precautions to avert the heat waves reaching a disaster level in Gaziantep, which is located in a position susceptible to heat waves due to its latitude and geographical conditions.
\end{abstract}

Keywords: Heat Waves, Apparent Temperature, hot days, trend, Gaziantep climate

\section{Introduction}

The effects of climate change go beyond the changes in the average temperatures and comprise negative shifts (Trenberth et al., 2007). In the scenario of a $2^{\circ} \mathrm{C}$ warmer world, almost every future will be as hot or hotter than the hottest that people + material, spiritual and physical impact in a global context. The IPCC (2012) reports concluded that there was an increase in the number of heatwaves since the mid-20th century and that it was very likely that the length, frequency, and / or intensity of these events would increase over the land areas of the 21st century. According to the dynamic model projections, the fact that frequency, intensity and duration of extreme temperatures will augment at least over the next century necessitates the observation of extreme temperatures in different climates and scales (Perkins, 2013) (OpitzStapleton, 2016). Studies on Europe and the Mediterranean region predict that the number and duration of hot extremes will rise and the number of cold extremes will decline (Kostopoulou, 2005; Tebaldi, 2006; Jones, 2008; Kuglitsch, 2010; Christidis, 2012; IPCC, 2012; Tanarhte, 2012; IPCC , 2013). Also, the studies on extreme temperatures, heat waves and heat index for Turkey, which is in the Mediterranean basin, verify the potential increase in the number and severity of extreme events (Unal, 2013; Deniz, 2013; Erlüt, 2015; Bölük, 2013; Deniz, 2003; Gönençgil, 2016). A hot day is defined as a day where the daily temperature exceeds the long-term daily 95th percentile of daily temperature (Della-Marta, 2007). In order for heat waves to emerge, hot days meeting these conditions must continue for at least three days. Extreme temperature events are customarily connected to large-scale anticyclonic weather systems. Heat wave features include positive radiation anomalies due to adiabatic warming, hot air advection and reduced cloudlessness (Black, 2004; Meehl, 2004). The atmospheric conditions controlling the formation of hot weather and hot air waves in Turkey are due to the strengthened and long-circulating southern sector surface and boundary layer winds and southern sector hot air advections which developed at a geopotential height of $850 \mathrm{hPa}$. This atmospheric circulation pattern results in the formation of much warmer weather conditions and warm weather waves, which can particularly be observed from June to the end of September (Erlat, 2015). The heat waves are formed by a ridge structure extending in the south-north direction. This structure carries warm air from Africa to the North (advection). Subsequently, adiabatic warming due to subsidence, which is one of the characteristics of high pressure systems, strengthens the effect of heat waves (Zittis, 2015). The annual 
variability of the heat waves arises from the lagged effects of ENSO (EI-Nino-South Oscillation) due to the increased water vapor reaction with increasing extreme temperatures following the hot ENSO events (Boutheina, 2017).

\section{Method}

2.1. Data and Location: The daily maximum temperature $\left({ }^{\circ} \mathrm{C}\right)$ and mean relative humidity $(\%)$ was collected from Turkish Meteorological Department for the period 196-2016 in order to calculate the heat waves (HW) and heat index (HI). Extreme events typically occur in mid-summer, although less intense heat waves are also experienced during spring and early autumn. In addition to the temporal tendency of the event, an extended summer season lasting 153 days (from May to September) was chosen in this study in order to reveal the spread of the event over the year. Gaziantep Meteorological Station, which is situated in an open and sensitive location to heat waves due to its climatic features, was chosen as the location of this study (Figure 1). It is forecasted that the effects of climate change on Turkey in the Mediterranean basin will increase in number and the duration of drought and extreme heat incidences (Erlat, 2015). In the city of Gaziantep, which shows the characteristics of Terrestrial Mediterranean Transition Climate in general (Turkes, 2010), it is observed that the maximum temperatures are high (average $38^{\circ} \mathrm{C}$ ), very low humidity (average $41 \%$ ) and severe evaporation conditions prevail in the summer season. The Mediterranean characteristic is a result of the natural order that constitutes the climate conditions. This is particularly evident from the highly distinctive summer drought and the concurrence of maximum rainfall with the winter season (Erinç, 1980).

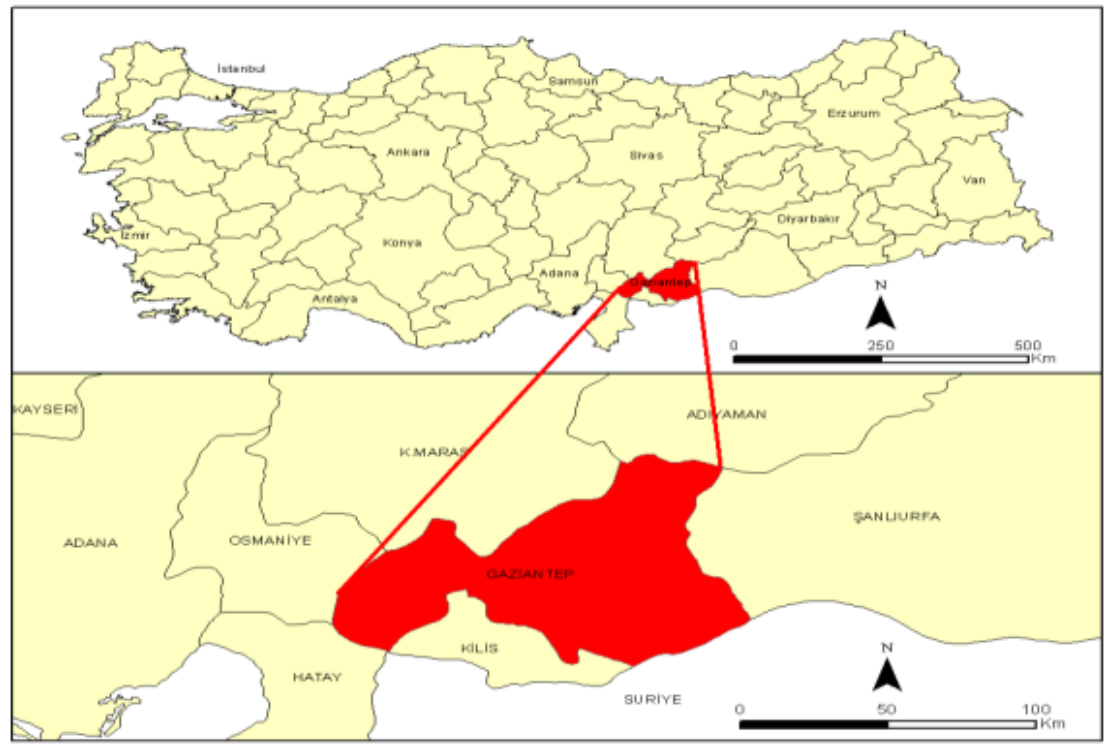

Figure 1: Location map of Gaziantep (37.0585 ${ }^{\circ} \mathrm{N}, 37.3510^{\circ} \mathrm{E}$ and $854 \mathrm{~m}$.)

Gaziantep is exposed to heat waves when it is under the effect of the Basra low pressure system. This phenomenon is also observed in the temperature parameters. Upon an examination of the summer temperature trends, it is evident that the impact of heat waves is intensified (Figure 2). 


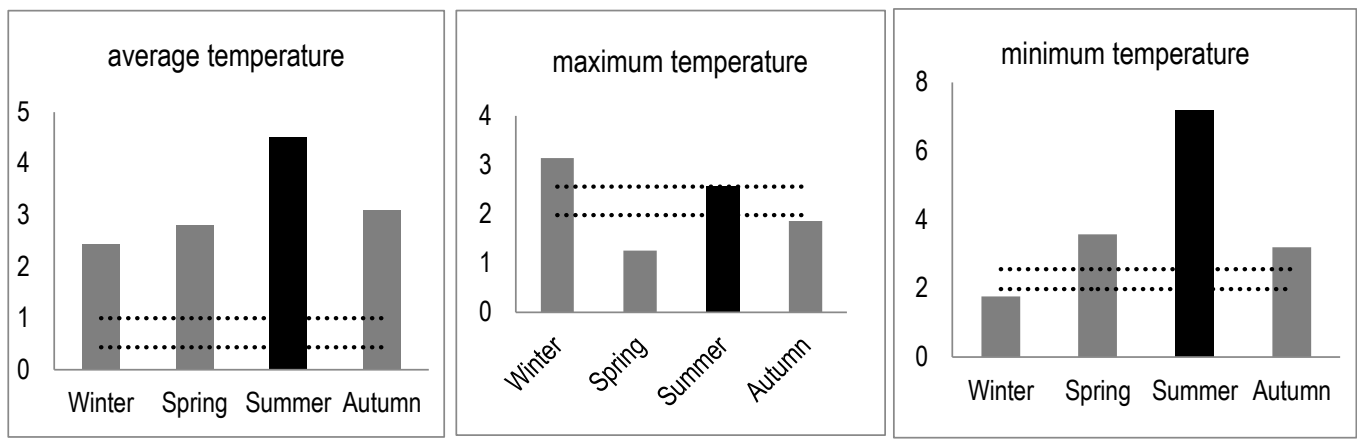

Figure 2: Seasonal trends of Gaziantep average, maximum and minimum temperature parameters.

2.2. Data Processing: The method includes a range of definitions that may be useful for a wide range of systems. Based on Fischer (2010) and Perkins (2012), a series of indices were calculated that characterize the persistence and severity of temperature wave events. The heat index was based on the works of Steadman (1984). The results were subjected to OLS and nonparametric Mann-Kendall test. The level of significance was calculated at $1 \%$ and $5 \%$. In this way, trends in temperature fluctuations and comfort values were examined by determining the magnitude and direction of the possible trend in the parameters.

Heat Waves Metrics: A heat wave: is defined as a minimum 3-day row when the daily maximum temperature is equal to and above the 95th percentile of the control period. 95th percentile is calculated for a fifteen-day window centered on each calendar day of the control period (1960-2016). The four basic characteristics of the heat wave (HWF, HWN, HWA, HWD) have been found out.

HWF95 (frequency): The average frequency of days meeting the heatwave criterion. HWN95 (number): The average number of heatwaves per summer. HWA95 (amplitude): The average peak temperature of the hottest heatwave per summer (years without heatwaves are excluded from the analysis). HWD95 (duration): The average duration of the longest heatwave per summer (years without heatwaves are excluded from this analysis).

Combined hot days and tropical nights (CHT): In addition to the heat wave characteristics, $\mathrm{CHT}$, which is a combination of tropical nights and hot days, was calculated. $\mathrm{CHT}$ refers to the days when the maximum temperature is above $35^{\circ} \mathrm{C}$ and the minimum temperature is above $20^{\circ} \mathrm{C}$ (Fischer, 2010) (Perkins S., 2015).

Heat Index (Apparent Temperature): In the context of Climatology, the recommended heat wave indices are quite high (Meehl, 2004; Fischer, 2010; Nairn, 2013; Stefanon, 2013; Schoetter, 2014; Vautard, 2013). Although there is some common ground covered by the Indices, no standard definition of heat waves has been available up until now (Suparta, 2017; Perkins, 2015). This makes it difficult to compare changes in heat waves, particularly at the regional scale (Perkins, 2015).

The heat wave varies relying on the length of consecutive days, the type of data temperature (minimum, average, maximum), the thresholds used to determine an extreme temperature, and whether humidity is taken into account (Perkins, 2012). In this study, the Apparent Temperature (Ta) developed by Steadman (1984) was used in order to reveal the change in comfort conditions (Steadman, 1984). The Heat Index (HI) or known as the "Apparent Temperature (Ta)" might also be considered when studying the heat wave event. The method was widely used in order to produce weather warnings in reallife situations. Steadman, translated combinations of relative humidity and temperature calculated in the same units as air temperature. As the impact of wind is ignored (indoor conditions), Apparent Temperature formula is expressed as

$$
\mathrm{Ta}\left({ }^{\circ} \mathrm{C}\right)=-1.3+0.92 \mathrm{~T}+2.2 e
$$

where $\mathrm{T}$ is ambient air temperature $\left({ }^{\circ} \mathrm{C}\right)$ and $e$ is saturation vapour pressure (kPa) (Steadman, 1984). 
Relative humidity; as a percentage of the ratio of observed vapor pressure to the saturated vapor pressure at the same temperature and pressure, the vapor pressure can be calculated as a function of the relative humidity using the equation (WMO, 2008):

$$
e=6.112 * \exp \left[\frac{17.62 t}{243.12+t}\right] * R H * 0,01
$$

where $t=$ air temperature (dry-bulb temperature)

$e=$ saturation vapour pressure in the pure phase with regard to water at the dry-bulb temperature.

$\mathrm{RH}=$ relative humidity

\section{Findings}

3.1. Heat Waves metrics: A set of six heatwave metrics was computed in order to enable a comprehensive analysis of heat wave characteristics (Table 1). The level of significance in the trend analysis was determined as $5 \%$ and $1 \%$. The maximum temperature thresholds (TX95pct) are above $30^{\circ} \mathrm{C}$ (average 35.8) at the Gaziantep Meteorological Station. The TX95pct statistically shows a strong positive trend at the $1 \%$ level. The increase in the threshold values is connected to the increase in the maximum temperature averages, and, hence, to the formation of heat waves. Seasonal average frequency of days (HWF) meeting the heat wave criteria varies from 3 to 21 days in the location chosen for the study. The average is less than 5 days. No significant change in trend analysis of HWFs was observed. However, it is predicted that possible increases in the HWF will lead to an increase in the HWD and HWNs. There is an average of 1.3 heat waves per year (No heat wave was observed for 10 years in the control period). The highest number of heat waves was observed in 1979 with 5 incidences. The change of HWNs is not statistically significant.

HWA is the heat wave amplitude that refers to the hottest day of the warmest heat wave (the peak of the warmest heat wave). The index for Gaziantep varied between 32.2 and $44^{\circ} \mathrm{C}$ between 1960 and 2016 with an average of $38.9^{\circ} \mathrm{C}$. This value is a result of Gaziantep's latitude and geographical features. According to the trend analysis, though the amplitude of the heat wave has a positive tendency in Gaziantep, it is not statistically significant. The average duration of heat waves in Gaziantep varies between 3 and 6 days. An average of about three days of heat waves is experienced each year. According to the trend analysis, the duration of heat waves does not show any significant change. In a study about the Mediterranean basin (Kuglitsch, 2010), it was determined that the Eastern Mediterranean was affected by shorter (less than 6 days) but more intense heat waves events in comparison to the previous decades (Kuglitsch, 2010). However, for example, CHT values, namely, the days with a combination of hot days and tropical nights, show a strong positive trend at $1 \%$ statistically. It is particularly noteworthy that the number of days meeting the $\mathrm{CHT}$ criteria in 1998, 2007, 2010 and 2016 is over 60. Similar results have been observed in the work of Barriopedro et.al.(2011) and Christiansen (2013). Christiansen found a generally upward trend in the same years (except in 2016) in his study on the changes in the summer period of high temperature extremes. Barriopedro et al.(2011), described 2003 and 2010 as "mega-temperature waves" because $50 \%$ of Europe exceeded the temperature records of about 500 years.

Table 1: Mean (min/max) Values and Trends of TX95pct, HWF95, HWN95, HWA95 and HWD95 from 1960 to 2016 using the Mann-Kendall test.

\begin{tabular}{llll}
\hline Metrics & Mean $(\mathbf{m i n} / \mathbf{m a x})$ & Z test & Significance \\
\hline TX $_{95 p c t}\left({ }^{\circ} \mathrm{C}\right)$ & $35,8(33,3 / 38)$ & 3,23 & ${ }^{* *}$ \\
HWF95 (days) & $4,5(3 / 21)$ & 0,17 & \\
HWN95 (days) & $1,3(1 / 5)$ & 0,12 & \\
HWA95 $\left({ }^{\circ} \mathrm{C}\right)$ & $38,9(32,2 / 44)$ & 0,78 & \\
HWD95 (days) & $2,8(3 / 6)$ & 0,10 & \\
CHT (days) & $34,3(10 / 66)$ & 4,9 & \\
\hline
\end{tabular}




\subsection{Apparent Temperature (Heat Index):}

The number of heat indexes per year was calculated according to average and maximum temperatures and trends were determined by OLS (not shown here) and Mann-Kendall test (Table 2). Since the average temperatures tend to increase in Gaziantep in general, this is also reflected in Ta values. The average temperature heat index $\mathrm{Ta}$ (avg) statistically showed a strong positive trend at $1 \%$ level. $\mathrm{Ta}(\max )$ values calculated for maximum temperatures showed a positive trend at $5 \%$ level.

Table 2: Trends in the number of heat indexes per year in terms of average and maximum temperatures

\begin{tabular}{|l|l|l|l|l|}
\hline Parameters & Time range & $\mathrm{n}$ & Test Z & Sign. \\
\hline Number of $\mathrm{Ta}$ (avg) & $1960-2016$ & 57 & 4,92 & *** \\
\hline Number of $\mathrm{Ta}$ (max) & $1960-2016$ & 57 & 2,34 & $*$ \\
\hline
\end{tabular}

$* * / * \star *$ indicates positive/negative trends at the $1 \%$ significant level

*indicates positive/negative trends at the $5 \%$ significant level

According to the apparent temperature categories, Taavg values show a strong positive increase at $1 \%$ level in the temperature variability (Table 3) in terms of the "caution" category statistics. In Tamax "caution" category, in contrast, strong negative sign ificance is observed. This does not mean that the maximum temperatures tend to decrease; On the contrary, the temperatures (maximum and mean) tend to increase in general and show an upward shift through time (discomfort level) in terms of heat index. Ta $\max$ values tend to increase strongly in the category of "extreme caution" by $1 \%$. In a study conducted by Deniz (2013) on summer days $\left(\geq 25^{\circ} \mathrm{C}\right)$ in Turkey about the trends in tropical days $\left(\geq 30^{\circ} \mathrm{C}\right)$, long-term upward trends in summer temperatures, are quite evident in the south of Turkey. The rising trends in temperatures are evident due to the decreasing number of summer days during the summer season and the increasing numbers of tropical days in the Southeastern Turkey. In the same study, the number of tropical days in the Southeastern Anatolia Region was calculated over 90-110 days. Taavg values which may be included in the "danger" category are not observed and Tamax values are in a tendency of positive increase which is not meaningful in the danger category.

Table 3: Temperature Trends According to Ta Categorizations Calculated Based on Maximum and Mean Temperature:

\begin{tabular}{|l|l|l|l|l|}
\hline Category & Time range & n & Test Z & Sign. \\
\hline Caution (Taavg) $\left(26-32^{\circ} \mathrm{C}\right)$ & $1960-2016$ & 57 & 4,62 & $* * *$ \\
\hline Extreme caution $\left(\right.$ Taavg) $\left(32-40^{\circ} \mathrm{C}\right)$ & $1960-2016$ & 26 & 0,94 & \\
\hline Danger (Taavg) $\left(40-55^{\circ} \mathrm{C}\right)$ & $1960-2016$ & - & - & - \\
\hline Caution $\left(\right.$ Tamax) $\left(26-32^{\circ} \mathrm{C}\right)$ & $1960-2016$ & 57 & $-3,59$ & $* * *$ \\
\hline Extreme caution $(\operatorname{Tamax})\left(32-40^{\circ} \mathrm{C}\right)$ & $1960-2016$ & 57 & 4,31 & $*$ \\
\hline Danger (Tamax) $\left(40-55^{\circ} \mathrm{C}\right)$ & $1960-2016$ & 57 & 1,55 & \\
\hline
\end{tabular}

$* * / * *$ indicates positive/negative trends at the $1 \%$ significant level

*indicates positive/negative trends at the $5 \%$ significant level

The distribution tendencies of the Tamax values according to the categories are calculated and presented in Table 4. Tendency calculations show that Tamax values tend to be strongly positive in the period from June to September, with June being very strong ( $1 \%$ level). This phenomenon indicates that the events of the heat wave predicted to happen during the summer season extend to the early autumn in Gaziantep. Therefore, it can be concluded that the synoptic conditions producing the heat wave in Gaziantep continues up until the beginning of autumn.

Table 4: Distribution trends of Tamax values by categories (1960-2016)

\begin{tabular}{|l|l|l|l|l|}
\hline Months & Time range & $\mathrm{n}$ & Test Z & Sign. \\
\hline May & $1960-2016$ & 57 & 0,43 & \\
\hline
\end{tabular}




\begin{tabular}{|l|l|l|l|l|}
\hline June & $1960-2016$ & 57 & 2,78 & ${ }^{*}$ \\
\hline July & $1960-2016$ & 57 & 2,45 & ${ }^{*}$ \\
\hline August & $1960-2016$ & 57 & 2,0 & ${ }^{*}$ \\
\hline September & $1960-2016$ & 57 & 2,12 & ${ }^{*}$ \\
\hline
\end{tabular}

${ }^{* \star} /{ }^{* \star *}$ indicates positive/negative trends at the $1 \%$ significant level

*indicates positive/negative trends at the $5 \%$ significant level

\section{Results and Evaluations}

Due to the geographical position of Gaziantep, it is situated in a sensitive location in terms of heat waves. With increasing migration in recent years, it has become one of the fastest growing cities in Turkey in terms of population (Sönmez, 2012). Accordingly, it is imperative to take precautions for the possible extremes of hot weather based on the changes in the climate. In this study, in which the characteristics of heat waves and comfort conditions in Gaziantep are presented, it is seen that the positive trends of heat waves as number, duration and frequency are not significant, but the threshold values used for heat waves show strong positive trends. CHT values demonstrate statistically positive significance levels. This shows that hot nights and tropical days have risen in number in Gaziantep based on the increase in minimum and maximum temperatures. The heat index ( $\mathrm{Ta}$ ) calculated on the basis of the relationship between average and maximum temperatures and relative humidity in terms of comfort levels has shown significant increases in both average and maximum Ta values. Considering the seasonal distribution of the heat index, there is an increase in the tendency of negative comfort conditions from June to September. Therefore, the negative conditions spread over the summer period extending to the early autumn period. It is vital to develop a strategy to minimize the negative effects of hot waves on the country and especially for early warning and mitigation efforts. Considering that data from only one meteorological station has been studied, only the temporal changes of the heat waves are presented in this study. Other stations in the Southeastern Anatolian Region may also be included in the study and the spatial changes in the region may be revealed further in the prospective studies.

\section{References}

[1] Barriopedro, D. F.-H. (2011). The hot summer of 2010:Redrawing the temperature record map of Europe. Sci.332(6026) , 220-224.

[2] Black, E. B. (2004). Factors contributing to the summer 2003 European heatwave. Weather 59(8): , 217-223.

[3] Boutheina Oueslati, B. P. (2017). Characterization of Heat Waves in the Sahel and Associated Physical Mechanisms. Journal of Climate 30:9, 3095-3115.

[4] Bölük, E. A. (2013). 2012 Temmuz ayında Yaşanan Sıcak Hava Dalgası. 6th Atmospheric Science Symposium - ATMOS 20133 - 5 Haziran 2013, İstanbul: ITÜ.

[5] Christiansen, B. (2013). 'Changes in Temperature Records and Extremes: Are They Statistically Significant?' Journal of Climate $26,7863-7875$.

[6] Christidis, N. S. (2012). Human activity and anomalously warm seasons in Europe. Int. J. Climatol. 32(2) , 225239.

[7] Della-Marta, P. M. (2007). Doubled length of western European summer heat waves since 1880. Journal of Geophysical Research, D15, 103-112.

[8] Demirtaş, M. (2017). Şiddetli sıcak hava dalgaları: dinamik-fiziksel etkenler ve bu sıcak hava dalgalarının özellikleri. SAÜ Fen Bilimleri Enstitüsü Dergisi, Cilt 21, Sayı 2, , 190 - 202.

[9] Deniz, Z.A. (2003). Marmara bölgesinde bunaltıcı sıcaklık analizi,. III. Atmosfer Bilimleri Sempozyumu, 19-21 Mart, ISBN.975-561-236-X. İstanbul: iTÜ.

[10] Deniz, Z.A. (2013). Türkiye'de Yaz Mevsimindeki Sıcak Günler ve Sıcak Günlerin Eğilimleri. Türk Coğrafya Dergisi, Sayı $61,1-10$.

[11] Erlat, E. (2015). Türkiye Rekor Maksimum ve Minimum Hava Sıcaklıklarının frekanslarında 1950-2014 Döneminde Gözlenen Değişmeler ve Atmosfer Koşullarıyla Bağlantıları . Ege Coğrafya Dergisil, VOL. 24 (2) , 29-55.

[12] Fischer, E. S. (2010). Consistent Geographical Patterns of Changes in High-Impact European Heatwaves. Nat. Geosci. 3 (6) , 398-403.

[13] Gönençgil, B. A. (2016). Extreme maximum and minimum air temperature in Mediterranean coasts in Turkey. . Russian Geogr. Soc. 9, 59-70. 
[14] IPCC. (2012). Managing the risks of extreme events and disasters to advance climate change adaption. . New York, NY: In: Field,C.B.,Barros, V., Stocker, T.F., et al.(Eds.),A Special Report of Working Groups I and II of the Intergovernmental Panel on Climate Change.

[15] IPCC. (2013). Climate Change 2013: The Physical Science Basis. Contribution of Working Group I to the Fifth Assessment Report of the Intergovernmental Panel on Climate Change. Cambridge University Press, Cambridge, United Kingdom and New York, NY, ABD, 1535: IPCC.

[16] Jones, G. S. (2008). Human contribution to rapidly increasing frequency of very warm northern hemisphere summers. . J. Geophys. Res. 113(D2) , D02109+.

[17] Kostopoulou, E. J. (2005). Assessment of climate extremes in the eastern Mediterranean. . Meteo. Atm. Phys (89):1, 69-85.

[18] Kuglitsch, F. ,.-M. (2010). Heat wave changes in the eastern Mediterranean since 1960. Geophysical Research Letters 37: , L04802.

[19] Meehl, G. T. (2004). More intense, more frequent, and longer lasting heat waves in the 21st century. Science 305 (5686) , 994-997.

[20] Nairn, J. F. (2013). Defining heatwaves: heatwave defined as a heat impact. Bureau: The Centre for Australian Weather and Climate Research, CAWCR Technical Report No. 060.

[21] Nairn, J. F. (2013). Defining heatwaves: heatwaves defined as a heat impact event servicing all community and business sectors in Australia. Australia: CAWCR Technical report No 060. The Centre for Australian Weather and Climate Research A partnership between the Bureau of Meteorology and CSIRO.

[22] NRC. (2011). Climate Stabilization Targets: Emissions, Concentrations, and Impacts over Decades to Millennia. Washington DC: National Research Council, National Academies Press.

[23] Opitz-Stapleton, S. S. (2016). Heat index trends and climate change implications for occupational heat exposure in Da Nang, Vietnam. Climate Services 2 , 41-51.

[24] Perkins, S. A. (2012). Increasing frequency, intensity and duration of observed global heat waves and warm spells. Geophys. Res. Lett. 39 , L20714.

[25] Perkins, S. (2015). A review on the scientific understanding of heatwaves-their measurement, driving mechanisms, and changes at the global scale. Atmos. Res. 164-165, 242-267.

[26] Schoetter, R. C. (2014). Changes of western European heat wave characteristics projected by the CMIP5 ensemble. Clim. Dyn. , 1-16.

[27] Sönmez, M. (2012). Yerleşme Yeri Seçimi ve Alansal Gelişimi Açısından Gaziantep. . Malatya: Özserhat Yayıncilık.

[28] Steadman, R. (1984). A Universal Scale of Apparent Temperature. J. Clim. Appl. Meteorology , 23 (1674-1687).

[29] Stefanon, M. D. (2013). Heatwave classification over Europe and the Mediterranean region.. Environ. Res. Lett. 7, 014023.

[30] Suparta, W. Y. (2017). An analysis of heat wave trends using heat index in East Malaysia. IOP Conf. Series: Journal of Physics: Conf. Series 852 (2017) 012005 (s. 012005). Kuala Lumpur, Malaysia: International Conference on Space Science and Communication.

[31] Tanarhte, M. H. (2012). Intercomparison of temperature and precipitation datasets based on observations in the Mediterranean and the Middle East. Geophys. Res. 117: , D12102. .

[32] Tebaldi, C. H. (2006). 'Going to the extremes; An intercomparison of model-simulated historical and futre changes in extreme events'. Climatic Change 79 , 185-211.

[33] Ünal, Y. T. (2013). Summer heat waves over western Turkey between 1965 and 2006. Theor App/ Climatol 112 ,339-350.

[34] Vautard, C. G.-D. (2013). The simulation of European heat waves from an ensemble of regional climate models within the EURO-CORDEX project. Clim. Dyn. 41, , 2555-2575.

[35] Zittis. G., H. P. (2015). Projected changes of heat wave characteristics in the Eastern Mediterranean and the Middle East. Reg Environ Chang. 